\title{
IMPACT OF CORONAVIRUS CRISIS ON SMALL AND MEDIUM-SIZED ENTERPRISES IN THE SLOVAK REPUBLIC
}

\author{
Katarína Belanová1
}

Received: April 22, 2021 / Revised: June 14, 2021 / Accepted: June 28, 2021

(C) Association of Economists and Managers of the Balkans, 2021

\begin{abstract}
The crisis caused by the coronavirus COVID-19 pandemic has hit the corporate sector from an economic point of view particularly hard. The forced closure of operations led to a dramatic drop in sales and disruption of normal cash flow. In this regard, SMEs have been affected the most. Because of their economic and social importance for the economies, governments have taken many measures to help them. This article aims to evaluate the impacts of the coronavirus crisis on small and medium-sized enterprises in the Slovak Republic. For this purpose, we surveyed 139 SMEs up to the end of 2020. The results of the survey show that the existing help from the state has not compensated for the loss of sales and losses that entrepreneurs have had to deal with. The negative impact of the measures related to the second wave of the COVID-19 pandemic was felt by up to $96 \%$ of the addressed SMEs. The article also includes proposals from interviewed SMEs regarding business support measures. In this regard, it is necessary to focus especially on eliminating the technical and procedural shortcomings of the measures.
\end{abstract}

Keywords: Small and medium-sized enterprises, COVID 19 pandemic, Financial support.

JEL classification G38 $\cdot$ G2 $\cdot$ L25

\footnotetext{
$凶 \quad$ katarina.belanova@euba.sk
}

1 University of Economics in Bratislava, Dpt. of Finance, Bratislava, Slovakia 


\section{INTRODUCTION}

The attention of governments, professionals and ordinary people all around the world is focused on addressing the consequences of the pandemic caused by the spread of COVID-19. However, in addition to measures aimed at prevention from further uncontrolled spread of coronavirus and the collapse of health systems, it is important to consider the state of the economy. Compared to the crisis of 2008, the current economic recession caused by the COVID-19 pandemic has a more significant impact on the business sector.

In Slovakia, the business sector is represented by small and medium-sized enterprises (SMEs) ${ }^{2}$. According to the Report on the State of SMEs prepared by the Slovak Business Agency (2020a), SMEs accounted for $99.9 \%$ of the total number of business entities in the Slovak economy in 2019 (i.e. 595,371 SMEs out of 596,042 enterprises totally). The development of SMEs in the SR is presented in Figure 1. In 2020, the number of SMEs - legal persons increased by $4.8 \%$ to 258,174. There were 328,916 active sole proprietors. SMEs accounted for $73.8 \%$ of employment in the corporate economy and contributed by more than half (54.9\%) to total value added in 2019 . They bring innovative products to the market, represent an important source of economic growth and they are of great importance in job creation.

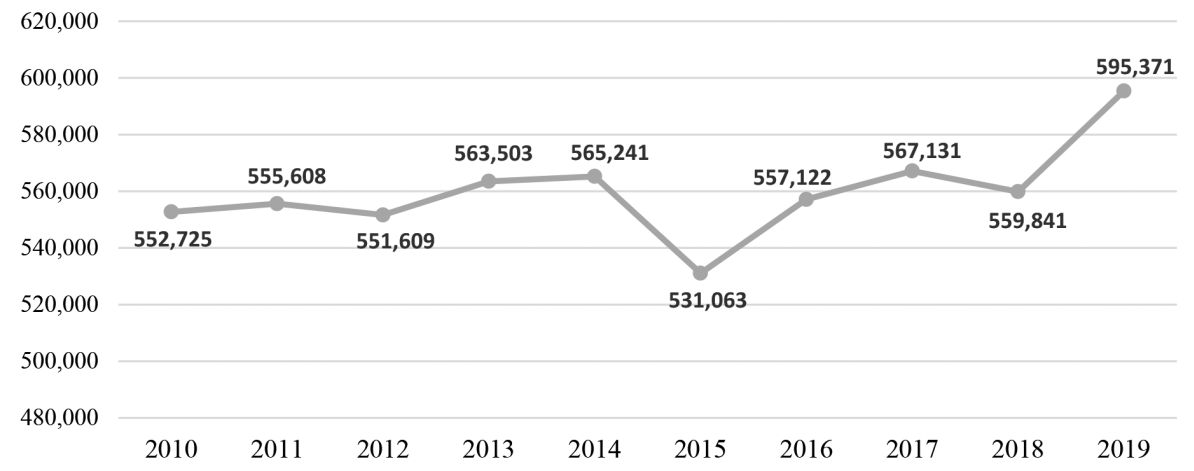

Figure 1. Development of SMEs in the SR

Source: Own processing according to data of the Statistical Office of the SR

Since the onset of the coronavirus crisis, many companies have not been using their capacity to the full for several reasons:

- the measures are taken to control the disease limit or make it completely impossible for entrepreneurs to carry out their business activities;

- $\quad$ employees must take care of children as a result of school closures;

- $\quad$ employees are not in good health;

- $\quad$ supply chains are interrupted or limited, leading to a lack of inputs necessary for business.

$2 \quad$ The size categorization of enterprises used in this article is in accordance with the recommendation of the European Commission no. 2003/361 / EC valid from 1.1.2005. The SME category consists of enterprises with less than 250 employees and the large enterprise category includes enterprises with 250 or more employees. Within the SME category, a distinction between micro-enterprises (0-9 employees), small enterprises (10-49 employees) and medium-sized enterprises (50-249 employees) is made. In cases where the category of micro-enterprises is not distinguished separately, all enterprises with the number of employees 0-49 are included among small enterprises. The criterion of the number of employees is not the only one that characterizes SMEs. The criteria of turnover, asset value and ownership structure are also taken into account. However, due to the unavailability of current data in the classification according to all SME criteria, we take the number of employees as a relevant criterion. 
Although companies of all sizes have been affected by the crisis, the category of SMEs is facing the greatest difficulties.

Due to their economic and social importance for the economies, surveying the business environment of SMEs, in particular their financing possibilities, has received considerable attention in the literature. The available research shows that this segment is affected by much greater complications in obtaining traditional forms of external financing compared to larger organizations. As we can find for example in the Report by the European Commission (2019), SMEs due to their characteristic features, are becoming particularly vulnerable to external shocks, esp. in terms of financing. SMEs typically find themselves at a disadvantage with respect to large firms in accessing debt finance. It is connected with their smaller size, a lower degree of diversification, more limited market and higher riskiness. In some cases, measures related to the saving of human lives have an existential impact on them.

Potential problems for SMEs can be caused by a relatively low level of digitization. In this regard, SMEs are not able to make sufficient use of their work capacity. SMEs will be more burdened by the cost of underutilized labor and technology equipment in the case of a decline in production than large companies.

According to the Analysis by Slovak Business Agency (SBA, 2020b), a total of 53,243 SMEs (i.e. $8.9 \%$ of active SMEs) operated in the sectors most affected by quarantine measures, and these were forced to close down completely in the first phase of the measures (from March to May). Within this group, micro-enterprises employing less than 10 employees were affected the most. They account for almost $96.2 \%$ of affected SMEs. In terms of legal form, sole proprietors, who make up almost two-thirds (59.7\%) of the total number of vulnerable SMEs, are the most affected group. Quarantine measures that required the closure of establishments, were generally operated by small and medium-sized enterprises in the areas of retail trade, accommodation and food service activities, transport and business and other services.

The impact of the pandemic on the Slovak economy may be in combination with a high degree of openness of the economy and, as a rule, with a limited number of SME suppliers, much more pronounced than in less open countries.

As table 1 shows, according to the European Payment Report (Intrum Slovakia, 2020), the most common crisis measures for companies include cost reduction, caution in indebtedness and restrictions on the recruitment of new employees.

Table 1. The most common measures taken by companies during a pandemic (percentage)

\begin{tabular}{|l|c|c|}
\hline Measure & Slovakia & Europe \\
\hline Cost reduction & 54 & 38 \\
\hline Greater caution when borrowing & 22 & 35 \\
\hline Restriction on the recruitment of new staff & 23 & 29 \\
\hline Identification of endangered segments & 18 & 29 \\
\hline Ensuring faster collection of payments from clients & 21 & 26 \\
\hline
\end{tabular}

Source: Own processing according to European Payment Report, 2020 
As the supply of manufactured products or services has decreased, so has the demand for goods and services. It causes a significant reduction in corporate incomes. In particular, consumers' fear and uncertainty raise consumers' concerns about loss of income, and, as a result, consumers are radically reducing consumption costs. The companies faced a significant drop in sales during the first, spring wave of the pandemic. During the summer months, the situation began to improve gradually. This improvement was extremely fragile and accompanied by significant risks. In autumn 2020, a second, even stronger wave of the pandemic broke out and the result was the introduction of even more significant restrictive measures at the end of 2020. While in 2020 the crisis mainly affected companies that were in a worse financial situation even before the crisis, in 2021 the crisis may get even healthier businesses into existential problems. Vaccination of the population could play an important role, but this will take some time.

In this context, the provision of rapid and effective assistance to prevent business closures is a major concern in all countries of the world.

While over the past decade, especially in Europe, consolidation has prevailed in the fiscal area and central banks have been the main actors in the fight against economic shocks, public finance is currently being activated to an unprecedented extent. Public resources are directed to a wide range of support programs, starting with funding for increased health system costs, through to employment support schemes and measures to compensate for revenue shortfalls in the corporate sector - either as a whole or specifically in the selected most affected sectors - up to capital injections into strategic companies.

A smaller part of the fiscal stimulus goes through the revenue side of budgets and takes the form of various concessions and deferrals for the payment of tax advances and levies. A third, and a significant, group of public sector assistance is loan guarantees, which are intended to support the availability of credit to businesses, in particular, to enable them to overcome temporary liquidity shortages.

It is clear that without these measures, the economic consequences of the coronavirus crisis would have been even more pronounced. This applies not only to the help drawn so far, but also to support measures to compensate for the negative effects of the crisis in the coming period. Given the existing imbalances in the business sector and the continuing uncertainty associated with the further development of the pandemic, the termination of individual support measures needs to be considered very sensitively. The main target group of ongoing support measures should be, in particular, promising companies with a sustainable business model, which need to bridge the temporary shortfall in sales.

The article aims to evaluate the impacts of the coronavirus crisis on small and medium-sized enterprises in the Slovak Republic. For this purpose, we surveyed 139 SMEs up to the end of 2020. Although some research on surveying the coronavirus' impacts has been conducted by several domestic organizations, academic engagement in this field is rare. The consequence is missing evaluation of the governmental measures taken to mitigate the consequences of the pandemic and recommendations for improvement of the environment of SMEs. Our motive for the survey was especially to fulfill the existing gap in the current empirical literature dealing with SMEs' environment and to propose measures for improvement of their current situation.

The results of the survey show that the existing help from the state has not compensated for the loss of sales and losses that entrepreneurs have had to deal with. The most endangered sectors of 
the Slovak economy include catering services, but also arts, entertainment, recreation and sports. The package of economic measures of the state to mitigate the economic effects of the corona crisis is insufficient.

The remainder of the paper is organized as follows. We start with the literature review, next section specifies the measures taken by the government of the Slovak republic to help SMEs to overcome the negative consequences of the coronavirus crisis, we continue by the description of the dataset used for the empirical analysis, then we present the results of the empirical analysis and outline our conclusions and recommendations.

\section{LITERATURE REVIEW}

Though the full economic impact of the pandemic is hard to predict, the literature offers starting points that can be useful in the evaluation of coronavirus crisis' impacts.

Didier et al. (2020) dispute the fact that the expectations regarding a problem-free functioning of companies after the pandemic can be very surprising. The authors state that companies have interrupted cash flows, which can trigger inefficient bankruptcies with long-term detrimental effects. Similarly, Lu et al. (2020) listed cash flow risks as the main difficulty regarding SMEs' survival due to numerous fixed expenses, but only when there's a low or no income. Their study also serves as an appeal for the creation of recommendations regarding work recovery, stimulation of consumption, and cash flow relief, all in order for SMEs to survive during the economic recovery followed by the COVID-19 pandemic.

Prohorovs (2020) introduces the need for a clear understanding of the COVID-19 crisis's specifics so that enterprises can adapt to the new situation faster while reducing damages. On the other hand, SMEs are more flexible and adaptable than their larger counterparts because of their small size, their tendency to be privately owned, and their relatively flat hierarchical structures, all of which can be beneficial during a crisis. Alves et al. (2020) state that the sudden drop in market demand influenced especially small enterprises. At the same time, small and young enterprises are highly flexible in the reaction to a crisis, mainly thanks to less bureaucracy and limited adherence to social responsibility.

As we can see, there are always two sides to the story. The crisis is always a certain milestone, a sudden interruption of the development of the economy. It is a way for the market to cope with bad decisions, reducing misinvestment. It should also be a source of lessons for the business sphere, an impetus for change and the search for new solutions.

Support for small and medium-sized enterprises is very important to ensure SMEs' sustainability in these difficult business conditions. Juergensen et al. (2020) state that the policy mix will need to shift from its initial focus on the survival of European SMEs in the short term, towards a more structural and longer-term approach based on promoting their renewal and growth through innovation, internationalization and networking.

Quantifying the effectiveness and quality of the measures taken, either individually or as a whole, is extremely challenging. State help in connection with the coronavirus crisis is constantly evolving. The conditions for individual state contributions are being updated, and new measures regulating (not only) the financial area are being approved. In general, however, the measures taken have one thing in common: it is the high time flexibility with which they were introduced. 
The Government of the Slovak Republic also reacted promptly to the pandemic and presented measures that should provide first aid for entrepreneurs, sole traders and employers affected by the crisis. The characteristics of the measures taken are the subject of the following text.

\section{COVID-19 MITIGATION MEASURES}

In response to the different development of the pandemic in individual countries, the governments of these countries have taken various measures.

The extent of measures responding to the health as well as the economic consequences of a pandemic varies from country to country, from almost none to about half of gross domestic product. This is also evidenced by Figure 2, which shows the total amount of the expected fiscal response to the pandemic in the EU countries, expressed as a percentage of GDP of individual countries.

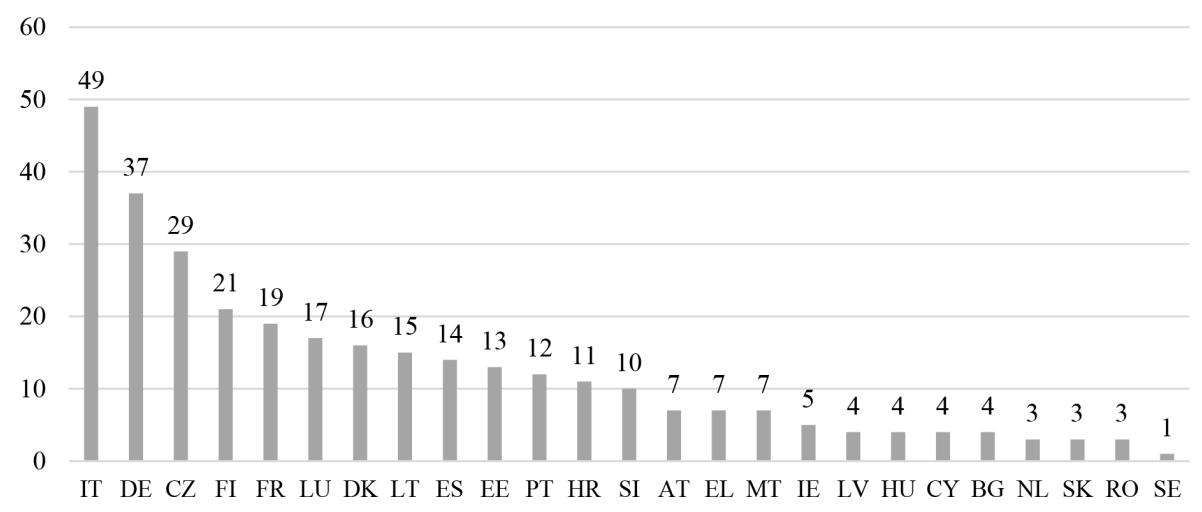

Figure 2. The total amount of fiscal measures expressed as a share of GDP Source: EU Independent Fiscal Institutions (2020), to June 2020

Funding spent by all EU Member States to combat the pandemic averages around 13\% of GDP. The Czech Republic, Germany and Italy are among the countries with the highest fiscal response to the pandemic. The largest volume of fiscal measures is in Italy. They amount to almost $50 \%$ of the country's GDP, of which $44 \%$ are public guarantees. Fiscal measures in Germany account for $37 \%$ of GDP. In the Czech Republic, state guarantees represent approximately $19 \%$ of GDP, while the overall fiscal response should reach up to $29 \%$ of the country's GDP. The smallest "packages" of fiscal support measures are in countries such as Sweden, Romania and Slovakia. Sweden has taken measures of only $1 \%$ of GDP, which can be explained by the fact that, unlike other EU countries, it has not introduced a national quarantine. Romania and Slovakia have taken measures to combat the pandemic of around 3\% of GDP.

The overall fiscal response stated as a percentage of GDP consists of direct and indirect fiscal measures. In all EU countries, direct measures prevailed, which are borne by the state budgets of individual countries. These measures include fiscal expenditures aimed at reducing unemployment and alleviating the short-term problems of companies with cash flows. Direct fiscal measures also include tax breaks, the main aim of which is to reduce the burden on taxpayers.

The second group of fiscal responses is indirect fiscal measures. The most common indirect fiscal measures are governmental guarantees for loans granted by financial institutions and loans 
granted directly by government institutions. These measures aim to facilitate access to working capital for companies and sole proprietors without an immediate and significant impact on the fiscal deficit. The several EU Member States have also decided to increase public investment in strategic corporations or infrastructure.

\subsection{SME Support Measures}

Regarding governmental measures to help businesses, there are differences in the targeting of measures in individual countries. In some countries, measures are available to all active businesses. In other countries, measures are granted to specific sectors or only to those companies that have experienced a significant drop in revenue. Finally, instead of focusing on the sectors most affected by the COVID-19 virus, countries focus on SMEs or sole proprietors, as they are expected to face much higher liquidity constraints compared to other businesses. The Czech Republic and Slovakia are also such countries.

Most countries have introduced measures to support SMEs - legal persons and the self-employed persons, mainly concentrated on maintaining short-term liquidity and employment. These measures take various forms in the following areas:

- Employment,

- Deferment of payments,

- Financial instruments,

- $\quad$ Structural policies.

Deferred income taxes, loan guarantees, direct loans and wage subsidies were the most widely used measures by individual governments to support SMEs in times of pandemic. The use of grants, debt moratoriums, or special measures for self-employed persons varies considerably across OECD countries.

According to the World Bank's findings by the end of 2020, a total of 1,600 measures have been taken to support SMEs in more than 120 countries around the world (Figure 3).

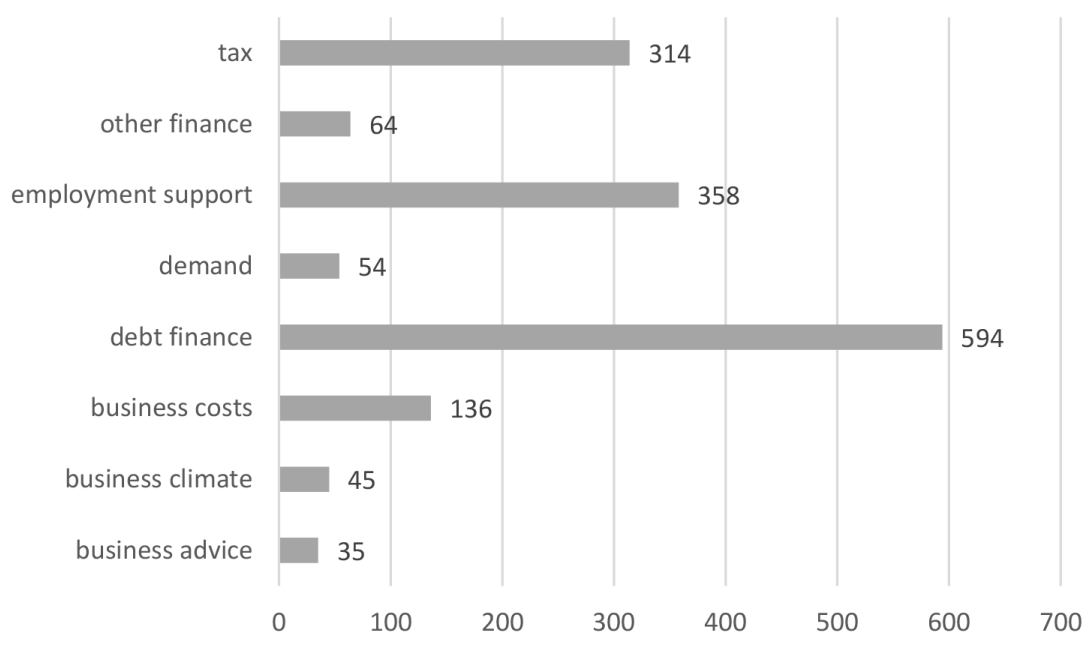

Figure 3. Number of SME support measures according to support type Source: World Bank (2020) 
As for Slovakia, measures in the area of structural policies have not been taken.

Within the framework of financial instruments which are of special importance to SMEs, the Government of the Slovak Republic responded to extraordinary circumstances by adopting several measures, in areas such as deferral of lease or loan repayments, bank guarantee from the state, subsidies but also by providing advantageous financial products and services through state financial institutions.

As of 31 July 2020, loans of EUR 136 mil. with a state guarantee for 1,437 companies were provided. In the first phase, only 3 de minimis guarantee schemes were available to companies, under which large companies were excluded from the beneficiaries. As a result, the main beneficiaries were mainly micro and small enterprises (cumulative $74 \%$ of the volume, but up to $93 \%$ of the number of enterprises). Of the total volume of newly granted loans for the period from May 2020 to July 2020 (micro-enterprises, small and medium-sized enterprises), loans with a state guarantee accounted for $14 \%$. In July 2020, banks began to provide loans from the so-called large guarantee scheme.

From the point of view of international comparison, Slovakia neither belongs to the active countries in the overall allocation, nor in the drawing of this form of aid to GDP. However, it should be mentioned that the use of this instrument is relatively modest among EU countries. Italy, Poland and Spain are among the most active countries in the use of this instrument. The possibility of deferring loan repayments is undoubtedly an important measure in the area of financial instruments.

By the end of July 2020, the deferral of repayments was approved for $12 \%$ of corporate loans. As table 2 reveals, the possibility of deferral of repayment was used to a greater extent by micro-enterprises and small enterprises and sectors significantly affected by the coronavirus crisis. However, this lower level is due to the fact that the legally defined deferral of installments does not apply to large companies that have agreed on deferral of installments individually with the financing bank. From the point of view of individual economic sectors, companies from the economic sectors most affected by the crisis made the most of the possibility of postponing installments. In the case of accommodation and food services, deferred loans account for half of the total loans, while in the arts, entertainment and recreation sector, these loans account for one-third.

Table 2. Share of deferred loans according to the size of the enterprise (in \%)

\begin{tabular}{|l|c|c|c|c|}
\cline { 2 - 4 } \multicolumn{1}{c|}{} & micro & small & medium & large \\
\hline Share of deferred loans & 15.0 & 15.2 & 11.8 & 5.9 \\
\hline $\begin{array}{l}\text { Share of loans granted to enterprises that have } \\
\text { been granted a deferral of repayments on at } \\
\text { least one loan }\end{array}$ & 17.7 & 19.5 & 21.0 & 13.1 \\
\hline
\end{tabular}

Source: Own processing according to the data of the National bank of Slovakia, data to September 2020

In an international comparison of EEA countries, Slovakia, with the volume of deferred loans to the total loan portfolio at the level of approximately $7.5 \%$ to the end of the first quarter of 2020 , ranked slightly above the EU average. Countries that make much greater use of this instrument include Cyprus, Hungary, Portugal, Malta, Italy, Croatia and Greece.

The nature of the setting and use of the deferral instrument varies across EU countries. Among the countries that have published the parameters of this instrument, the deferral lasting from 3 
to 6 months is the most widespread, while in Slovakia almost half of the deferred loans had an approved deferral of 6 to 9 months.

\subsection{Research Methodology}

Within the secondary research (desk research), available secondary sources of data and information on the impacts of the coronavirus crisis were processed, for example, reviews, articles, publications and websites (especially those of Statistical Office of the Slovak Republic, Ministry of Economy of the Slovak Republic, Ministry of Finance of the Slovak Republic, Slovak Business Agency). Because it is a worldwide problem, international materials dealing with this issue, e.g. World Bank (2020), resp. OECD (2020), were also surveyed.

The primary data were collected to investigate the views of self-employed, small and medium-sized enterprises on the anti-pandemic measures taken in connection with the second wave of the corona crisis, as well as obtaining information on preferred support measures based on a survey questionnaire.

The survey of the business environment was carried out on a sample of 139 entrepreneurs in the period 1.9.2020 - 30.11.2020. We used the method of non-random deliberate selection when selecting the sample, as we tried to select the respondents to include small and medium-sized enterprises active in the most affected sectors (accommodation services, catering services, arts, entertainment, recreation, sports, education, retail) and all regions of Slovakia. We contacted the selected SMEs via email.

In total, 3,400 SMEs were approached. The response rate was $4.1 \%$. The questionnaire contained 7 open and closed questions, the results of which are presented in the next section. To increase the explanatory power of the questionnaire, we compared our results with the results of two similar surveys conducted in the Slovak Republic in 2020.

\subsection{Results and Discussion}

Up to $96 \%$ of the addressed companies in the most endangered sectors felt the negative effects of the adopted anti-pandemic measures in connection with the second wave of the Covid-19 pandemic in Slovakia (as of 15 October 2020, ie before the decision on the partial lockdown of Slovakia).

Most entrepreneurs, who feel the significant negative effects of the measures taken, work in catering services, but also arts, entertainment, recreation and sports. As many as 9 out of 10 entrepreneurs from the Bratislava region expect a significant impact on the measures taken.

The adopted anti-pandemic measures until 15 October 2020 did not have a negative impact on only $4 \%$ of companies operating in the most endangered sectors of the Slovak economy.

Figure 4 shows the wide range of loss reduction measures implemented by SMEs in response to the second wave of the coronavirus crisis.

According to the answers of entrepreneurs, during the first wave of the coronavirus crisis (MarchMay 2020), up to $95 \%$ of the addressed SMEs from the most endangered sectors recorded a decrease in sales, while most companies, more than one third, recorded a significant drop in sales by more than $80 \%$. A decrease in sales of up to $50 \%$ in the first wave was declared by $41 \%$ of SMEs. 


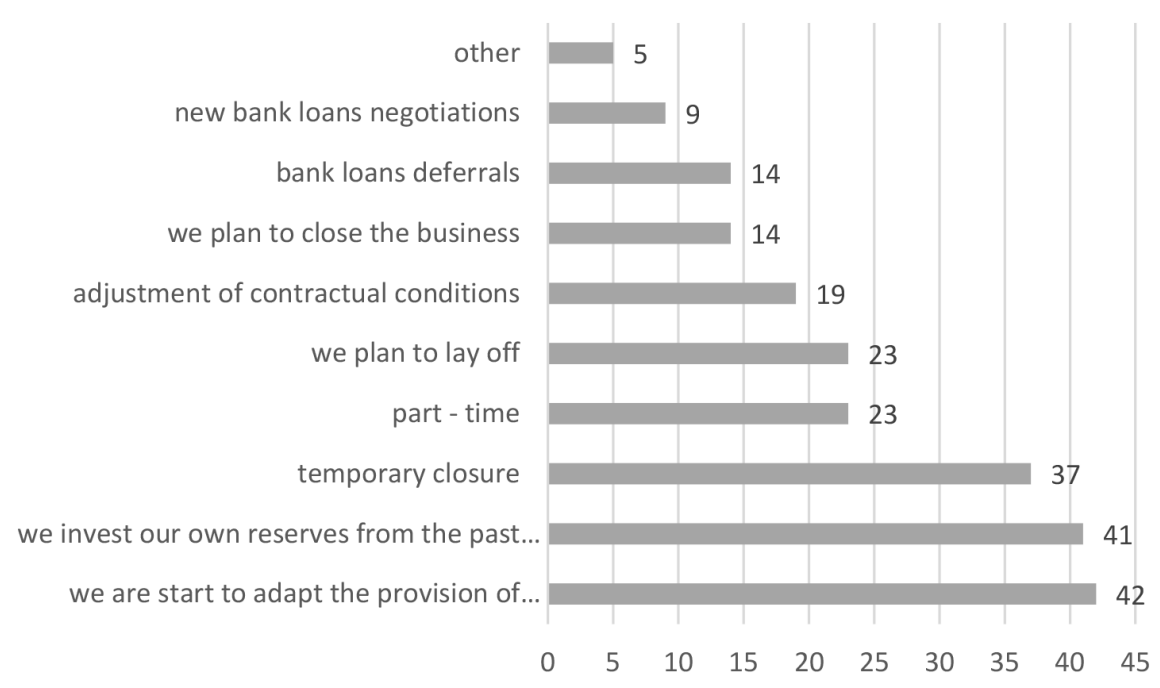

Figure 4. Measures introduced in business in response

to the second wave of the coronavirus crisis (\%)

Source: Own data collection

A little bit lower share, $93 \%$ of SMEs recorded a decline in sales even in the second wave of the crisis (Figure 5).

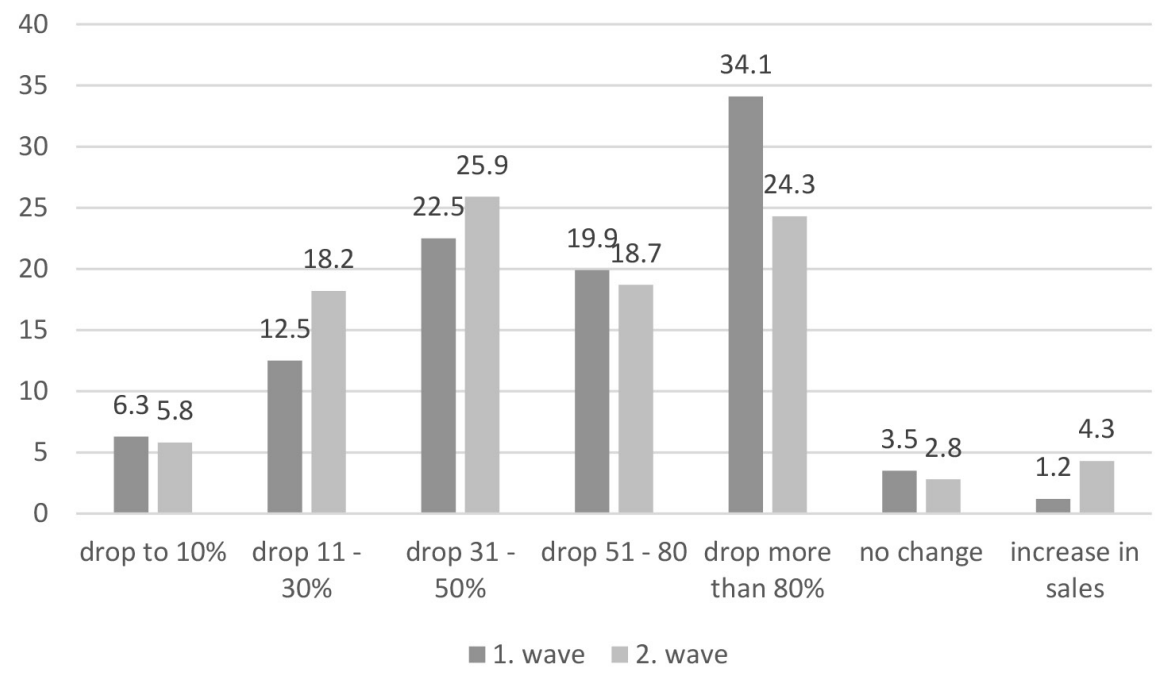

Figure 5. Year-on-year change in sales

Source: Own data collection

A survey conducted by the Centre for Better Regulation (2020) shows that almost 34\% of SMEs expected a drop in sales of up to $100 \%$ during the first spring wave of the coronavirus crisis. This survey was conducted among 53 entrepreneurs in the period between $31.03-13.04 .2020$, i.e. it included the effects of restrictive measures adopted by the Slovak government. 
Almost half of the surveyed SMEs from the most vulnerable sectors (48\%) in the survey stated that they could not do business for more than 2 months with the current restrictions (restrictions valid on 15 October 2020). The current situation is perceived most critically by $15 \%$ of the surveyed representatives of companies, which assume that they will end their business within one month. The results showed that companies in the catering and accommodation services sector are also at risk, as start-up entrepreneurs who have not been able to create sufficient reserves in the past to overcome unprecedented times.

In connection with the introduction of anti-pandemic measures, more entrepreneurs expect more significant assistance than in the first wave. The results of the survey suggest that the existing aid from the state did not compensate for the fall in sales of entrepreneurs in Slovakia. The decrease in sales was significantly higher than the aid provided by the state for $64 \%$ of the addressed companies. The worst situation is among entrepreneurs in the gastronomy sector, where more than half (73\%) of entrepreneurs recorded a significantly higher decline in sales than state aid (Figure 6).

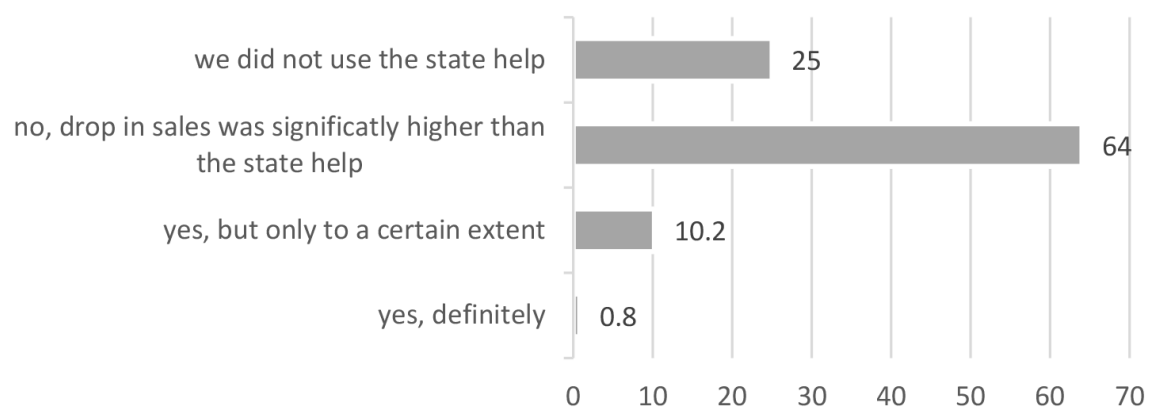

Figure 6. Was the existing assistance from the state able to compensate you for and the loss of sales since the beginning of the outbreak of a pandemic (\%)?

Source: Own data collection

The seriousness of the current situation for entrepreneurs in Slovakia is also documented by their proposals for business support measures, which we present in Figure 7.

The results of our survey largely coincide with the results of a survey conducted by the Slovak Business Agency (SBA, 2020c) on a sample of 1,043 respondents between 15.5 - 22.5.2020, to seek the views and experiences of micro, small and medium-sized enterprises in using support measures to mitigate the effects of the corona crisis.

Its results reveal that more than half (56.1\%) of small and medium-sized entrepreneurs consider the package of economic measures of the state to mitigate the economic effects of the corona crisis to be insufficient.

Measures taken are the most critically perceived by entrepreneurs from the catering sector (76.1\%), accommodation (69.2\%) and arts, entertainment and recreation (63.9\%), which include e.g. sports activities or realization of events. On the contrary, they are the least critically perceived by entrepreneurs in the construction industry. 


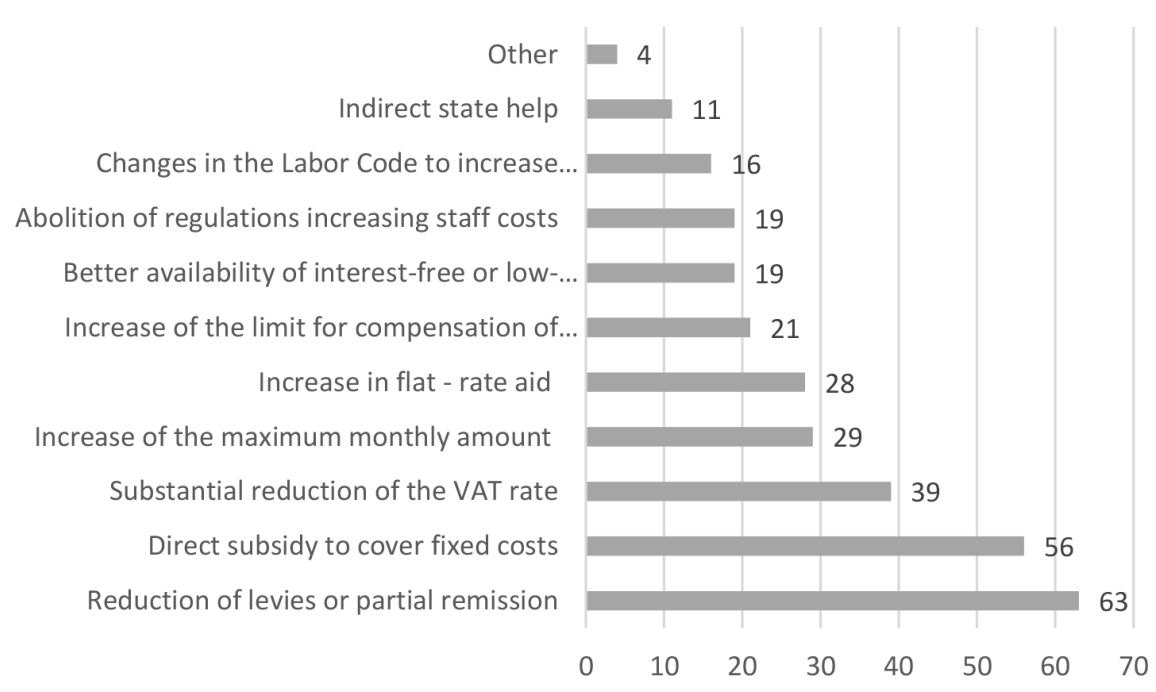

Figure 7. What support measures would help your business the most in relation to the current restrictions? (select max. 3 possibilities)

Source: Own data collection

Addressed entrepreneurs, who applied for state aid criticize in particular the complexity of support measures and the problematic orientation in them (22.9\%). Another problem is the ambiguity of the information provided on the possibilities of using the support (16.9\%).

Representatives of SMEs call for the need to adopt several changes to the current support system. Entrepreneurs would especially welcome the simplification of the conditions for obtaining support (23.5\%), the simplification of applications for support (18.1\%) and the improvement of awareness of the possibilities and ways of support drawing (15.2\%).

\section{CONCLUSION}

The ongoing pandemic of the new COVID-19 virus has affected the world not only in terms of health but also in terms of politics and economics. Restrictions due to quarantine and preventive measures in response to the pandemic have affected the economic activity of all countries in the world. The economic consequences of this situation will be felt by companies of all sizes, but above all by the most vulnerable group of companies, which is micro, small and medium-sized enterprises.

The available research shows that this segment is affected by much greater complications in obtaining traditional forms of external financing compared to larger organizations. This often has a negative impact on the prosperity of the business and can significantly affect its future. Due to the continuous decline in revenues and excessive fixed costs, it is necessary to provide aid and support to these enterprises to overcome this exceptionally unfavorable situation.

The scope and form of the measures taken vary from country to country. Some countries focus mainly on employment promotion, others on deferral of payments or financial instruments. However, most countries (as well as Slovakia) use a combination of support measures focused on different areas. 
Based on the findings of our survey on the business environment, as well as on the basis of objective data from the financial assistance provided by the state so far, we conclude that financial assistance from the state is not used as expected. We present several alternative proposals, the application of which would remove barriers to access or entitlement to aid, thus creating a precondition leading to an increase in its use by entrepreneurs:

- Elimination of technical and procedural shortcomings of measures. These cause that measures in the form of financial contributions are - due to the administrative complexity of applying for and obtaining them - more criticized than appreciated;

- Simplification of disproportionately strict conditions for obtaining financial assistance, which means that many entrepreneurs do not qualify for assistance or the amount of aid granted is insufficient;

- Mitigation of the consequences of identifying any deficiencies in the retrospective control of the use of financial assistance, consisting in declaring the full amount of the contribution to be reimbursed in the case of any deficiencies being identified;

- Testing the functionality of the measures on the target group before putting them into practice, which would prevent some of the above-mentioned as well as subsequently eliminated shortcomings and errors within the measures;

- $\quad$ Finding and comparing existing and implemented solutions in the surrounding countries;

- Application of innovative and creative measures without impact on public finances

- Primary provision of aid to the most affected sectors, with an emphasis on the most vulnerable groups of businesses - SMEs

- Coordination of all public authorities with the aim of timely, correct and up-to-date information. We consider it appropriate to cover all state measures to help entrepreneurs in times of corona crisis with an extensive information campaign that clearly and comprehensibly explains who is the eligible recipient of aid and what the aid consists of.

Moreover, we think that the coronavirus crisis is a suitable opportunity to open the topic of the overall regulatory burden on entrepreneurs in the Slovak Republic. At the same time, any crisis is an opportunity to change those rules that proved to be ineffective.

\section{REFERENCES}

Alves, J. C. et al. (2020). Crisis Management for Small Business during the COVID-19 Outbreak: Survival, Resilience and Renewal Strategies of Firms in Macau. Available at: https://doi. org/10.21203/rs.3.rs-34541/v1[Accessed: 26.6.2021]

Didier, T. et al. (2020). Financing firms in hibernation during the COVID-19 Pandemic. World Bank. Available at: https://doi.org/10.1596/33611[Accessed: 25.6.2021]

Centre for better regulation (2020). Testovanie vplyvov korona krízy a prijatých vládnych opatrení na MSP. [online]. Available at: http://lepsiezakony.sk/wp-content/uploads/2020/06/ Test-MSP_vplyvy-korona-krizy-na-podnikanie-MSP_MAR.pdf [Accessed: 15.4.2021].

European Commission (2019). Annual report on European SMEs 2018/2019 Research and Development and Innovation by SMEs, Luxembourg. Available at: https://op.europa.eu/en/ publication-detail/-/publication/cadb8188-35b4-11ea-ba6e-01aa75ed71a1/language-en [Accessed: 25.6.2021]

EU Independent Fiscal Institutions. European Fiscal Monitor Available at: https://www.euifis.eu/ download/european_fiscal_monitor_special_updatevol2_01.pdf [Accessed: 25.6.2021

Intrum (2020). European Payment Report 2020. [online]. Available at: https://www.intrum.com/publications/european-payment-report/european-payment-report-2020/ [Accessed: 15.4.2021]. 
Juergensen, J., Guimón, J. \& Narula, R. (2020). European SMEs amidst the COVID-19 crisis: assessing impact and policy responses. J. Ind. Bus. Econ. 47, 499-510. Available at: https:// doi.org/10.1007/s40812-020-00169-4[Accessed: 25.6.2021]

Lu, Y., Wu, J., Peng, J., \& Lu, L. (2020). The perceived impact of the Covid-19 epidemic: evidence from a sample of 4807 SMEs in Sichuan Province, China, Environmental Hazards. Available at: https://doi.org/10.1080/17477891.2020.1763902 [Accessed: 25.6.2021]

Prohorovs, A. (2020). Getting Ready for Recession: How SMEs Prepared for Covid-19 Pandemic and Economic Recession (May 7, 2020). Forbes (Latvian edition) No. 11, May 2020, pp. 4649. Available at: https://ssrn.com/abstract=3596611 or http://dx.doi.org/10.2139/ssrn.3596611 [Accessed: 25.6.2021]

SBA (2020a). Report on the state of Small and Medium Enterprises in the Slovak Republic in 2019. [online]. Available at: http://www.sbagency.sk/en/state-of-small-and-medium-entreprises [Accessed: 5.4 .2021$]$.

SBA (2020b). Analýza malých a stredných podnikov pôsobiacich v odvetviach najviac zasiahnutých karanténnymi opatreniami. [online]. Available at: http://monitoringmsp.sk/wp-content/uploads/2020/04/Anal\%C3\%BDza-MSP-p\%C3\%B4sobiacich-v-odvetviach-najviac-zasiahnut\%C3\%BDch-karant\%C3\%A9nnymi-opatreniami.pdf [Accessed: 17.3.2021].

SBA (2020c). Štátnu pomoc treba zjednodušit' a prestat' strašit' sankciami. [online]. Available at: http://www.sbagency.sk/sites/default/files/2020-05-26-ts-korona-prieskum-vysledky.pdf [Accessed: 15.4.2021].

World bank (2020). Map of SME - Support Measures in Response to COVID - 19. online]. Available at: https://www.worldbank.org/en/data/interactive/2020/04/14/map-of-sme-support-measures-in-response-to-covid-19 [Accessed: 15.4.2021]. 